\title{
Assessment of Ostrom's social-ecological system framework for the comanagement of small-scale marine fisheries in Colombia: from local fishers' perspectives
}

\author{
Darlin Botto-Barrios $^{1,2}$ and Lina M. Saavedra-Díaz ${ }^{2}$
}

\begin{abstract}
Fishery resource management under extractive production models in the Anthropocene has contributed to the collapse of fish stocks, threatening the food and livelihood security of many people, especially fishers. Common-pool resource theory has established the relevance of the design principles of Elinor Ostrom, which favor collective actions for the management of these resources. With the help of small-scale fishers, we assessed the state of Ostrom's principles in the study system to determine the conditions required to implement fishery comanagement in the future. The communities of Taganga (Caribbean coast) and Tumaco (Pacific coast), Colombia, served as case studies because of their known dependence on fishing and because both communities are currently facing a social-ecological crisis within their top-down administrative frameworks. We performed six hearings, three in each community in 2009 , 2012, and 2014, in which fishers brainstormed about the weaknesses that are closely related to Ostrom's social-ecological system framework. Additionally, 14 focus groups with 119 fishers (31 in Taganga in 2015; 88 in Tumaco in 2017) were conducted, one for each major fishing method used in each community. The obtained results made it possible to establish a community vision on the condition of the principles in each community, and the principles were prioritized by the fishers do determine which ones need immediate attention. The inhabitants of both Taganga and Tumaco expressed the urgent need to establish clear biophysical limits among resource users, to gain the participation of all actors involved, and to build nested enterprises. In particular, the community of Tumaco considered monitoring resources and regulations, establishing graduated sanctions, and recognizing basic rights to be priorities. Furthermore, future opportunities and conflicts related to fishery comanagement implementation were evident in both communities. Therefore, our results indicate that Taganga and Tumaco are not yet ready to implement fishery comanagement. Nevertheless, they have the knowledge and motivation to overcome the obstacles that prevent them from moving forward with managing their fishery resources and to face the tragedy of the commons.
\end{abstract}

Key Words: Anthropocene; fishery comanagement; local ecological knowledge; small-scale fishing; social-ecological systems

\section{INTRODUCTION}

Small-scale marine fishing is recognized globally as the main economic activity of coastal communities because it contributes to the food and livelihood security of the inhabitants of such communities (Food and Agriculture Organization 2012, Belhabib et al. 2015). However, a large proportion of the fish stocks that support this activity is overexploited (United Nations Environment Programme 2007, 2012, Food and Agriculture Organization 2012) as a consequence of human activities and their considerable planetary impacts (Jackson et al. 2001, Aswani et al. 2017, Redmore et al. 2018). Community-based approaches to the conservation and management of natural resources are considered appropriate to meet the challenges of this era (Ostrom 2009, Gadgil et al. 2002, Redmore et al. 2018). Consequently, efficient governance in coastal communities is key for sustainable fishery resources and for global fisheries (Anderson and Seijo 2010, Torres-Guevara et al. 2016).

In most Latin American countries, coastal and fishery management have been adopted based on a centralist approach, with state (top-down) controls imposed on fishery resources (Agüero and Claverí 2007, Salas et al. 2007). However, such topdown management regimes are rarely successful (Feeny et al. 1990, Ostrom 2005, Trimble and Berkes 2015). At present, there is a global trend toward the adaptive comanagement of the fisheries sector based on the theory of the commons and collective action, which states that it is possible that people may act collectively to manage common-pool resources in a sustainable manner (Ostrom
1990, Poteete et al. 2010). Given its great efficiency, the adaptive comanagement of fisheries has been proposed as a solution to overcome the current resource crisis (Pomeroy 2007, Evans et al. 2011, Cinner et al. 2012, Trimble and Berkes 2015).

Adaptive comanagement is a long-term collective action strategy that allows interested parties to share responsibilities within a specific natural resource system. Furthermore, such a strategy enables these parties to learn from their actions, ensuring sustainable local use of available resources (Ruitenbeek and Cartier 2001, Olsson et al. 2004, Armitage et al. 2007, Berkes 2009). Adaptive comanagement is based on the formulation of legal agreements that are politically negotiated between local residents (direct resource users) and different administrative levels. Through these agreements, residents are given the responsibility of making decisions regarding access to and use of natural resources in exchange for guaranteed benefits. Adaptive comanagement is appropriate for managing social-ecological systems (SESs), which require participatory approaches in terms of the interaction, deliberation, learning, and participation of stakeholders from the community and government (Schusler et al. 2003, Berkes 2010, Trimble and Berkes 2015).

Fishery comanagement has been implemented in the fisheries sector as an alternative management strategy (Wilson et al. 2003, Pomeroy and Rivera-Guieb 2006), and the strategy is considered a realistic solution to the problems faced by the world's fisheries (Gutiérrez et al. 2011). Fishery comanagement grants fishers

${ }^{1}$ Grupo de Investigación Evolución y Ecología Pesquera (GIEEP), University of Magdalena, ${ }^{2}$ Grupo de Investigación en Sistemas Socioecológicos para el Bienestar Humano (GISSBH), Department of Biology, University of Magdalena 
greater responsibility and authority over fishery resource management and greater participation in the decision-making process. The strategy can be defined as an agreement in which both the fishery administrative body and fishers share responsibilities and authority over fishery management (Wilson et al. 2003, Pomeroy and Rivera-Guieb 2006). Furthermore, such a strategy is almost always based on shared beliefs regarding democracy, transparency, accountability, organization, participation, subsidiarity, association, ownership rights, distribution of power, and sustainability (Jentoft 2003).

In Latin America, fishery comanagement has been implemented in small-scale fishing. In Mexico, for example, institutional agreements have been developed regarding the conditions for access to resources, such as territorial use rights in fisheries (TURF) and provisions for marine tenure (Castilla and Defeo 2001, Costello and Kaffine 2008, McCay et al. 2014, Crona et al. 2017). Additionally, Costa Rica has three marine areas of responsible fishing that are officially recognized by the Instituto Costarricense de Pesca y Acuicultura (Costa Rican Institute for Fisheries and Aquaculture; Fargier et al. 2014, García Lozano and Heinen 2015). Furthermore, Panama has presented a draft of the new Fisheries, Aquaculture, and Related Activities General Law prepared by Panama's Aquatic Resources Authority (Autoridad de los Recursos Acuáticos de Panamá 2016). In line with these initiatives, Chile has made efforts to comanage benthic resources by implementing seasonal closures and management and exploitation areas in the central zone of the country (Castilla and Fernandez 1998, Castilla and Defeo 2001, Schumann 2007, Gelcich et al. 2010, 2019). During the last decade, fishery management bodies in Brazil have included guidelines and participatory frameworks in legislation that have fostered fisher engagement in decision-making processes under the framework of marine extractive reserves and sustainable use protected areas (Seixas et al. 2009, Silva et al. 2013, Trimble et al. 2014).

In Colombia, small-scale fishers have not been recognized as an important part of the fishery management process (Cuello and Duarte 2010, García 2010, Saavedra-Díaz et al. 2015b). The work of fishers is not recognized as employment because of the negation of fishing activity by policy makers (Berkes et al. 2001, Bené 2006). The fundamental rights (work and decent housing) of fishing communities are violated. Furthermore, small-scale marine fisheries do not contribute to the gross domestic product but to local economies, and this contribution is not evident because of a lack of traceability and marketing chains (SaavedraDíaz et al. 2015a, 2016).

However, in the last decade, the engagment of small-scale Colombian fishing communities in comanagement has been acknowledged as being effective and as reducing the trend toward resource overexploitation (Saavedra-Díaz et al. 2016). Similarly, fishing communities consider comanagement a viable strategy for ensuring the sustainability of Colombian fishery resources and for demonstrating the need to establish joint regulations between the fishing authority and resource users (Saavedra-Díaz et al. 2014, 2015a,b). These communities have formal and informal regulations promoted by local stakeholders, although fishery comanagement has not yet been fully implemented (SaavedraDíaz et al. 2015b, 2016, Jiménez-Torres and Saavedra-Díaz 2019). Along the Colombian Pacific coast, there is a tendency to implement control measures throughout a fishing area, such as the exclusive zone of artisanal fishing (ZEPA, as abbreviated in Spanish) in the North Chocoan Pacific (Navia et al. 2010, Ramírez-Luna 2013), an integrated regional management district comprising the Golfo de Tribugá-Cabo Corrientes (Decree $2372 / 10$ ), the national district of integrated management comprising Cabo Manglares, Bajo Mira, and Frontera (Resolution 2299/17), and Uramba Bahía Málaga National Natural Park, an integrated management protected area in Valle del Cauca (Resolution 1501/10). Importantly, diagnostic reviews have also been performed regarding fishery management strategies that empower fishing communities along the Colombian Pacific coast (Zapata 2005, 2006, Beardon 2008, Navia et al. 2008) and the Caribbean coast (Corporación para el Desarrollo Sostenible del Urabá 2005, Fundación Ecosfera 2006, Mendoza et al. 2008, Santos-Martínez et al. 2013). In this regard, the efforts made during the last decade reflect the need to understand fishery management schemes in an integrated way, for example, by engaging all fishery-related stakeholders.

Authors such as Ostrom (1990), Berkes et al. (2001), Pomeroy et al. (2004), and Cox et al. (2010) describe the necessary conditions for managing common-pool resources. However, these conditions are not always sufficient. Some authors suggest that they are necessary conditions for the sustainable management of common-pool resources, depending on the general characteristics of the SES (Ostrom et al 2007, Baggio et al 2016). In the case of fisheries, these frameworks should be tailored to the particular context of each fishery (Armitage et al. 2009, Trimble and Berkes 2015) because the solutions that may be applicable in a given scenario may be useless in other contexts (Ostrom 1990, Basurto et al. 2013, Orensanz et al. 2013, Torres-Guevara et al. 2016). In 1990, Ostrom developed eight principles (i.e., clear boundaries, monitoring, collective choice, graduated sanctions, rule congruence, conflict resolution mechanisms, minimal recognition of rights, and nested enterprises; Table 1) that include suggested conditions for the sustainability of the commons and collective action; these principles were later validated by Cox et al. (2010) and Baggio et al. (2016). Because fishery comanagement is a collective action strategy, these principles have been used to assess fishery governance (Gelcich et al. 2006, 2019, Pomeroy 2007, Armitage et al. 2009, Fleischman et al. 2014, Galappaththi and Berkes 2015, Trimble and Berkes 2015).

The adaptive comanagement of fishery resources has shown positive results in Latin America and the Caribbean (Costello and Kaffine 2008, Gelcich et al. 2010, 2019, Silva et al. 2013, Fargier et al. 2014, McCay et al. 2014, García Lozano and Heinen 2015), and contemporary fishing communities in Colombia have shown the will to become involved in fishery management. Consequently, our research aims to evaluate the feasibility of implementing the participatory management of small-scale marine fisheries in the states of Magdalena and Nariño from the perspective of local fishers through the use of Ostrom's SES framework. The design of this research includes the examination of two case studies, Taganga (on the Caribbean coast) and Tumaco (on the Pacific coast), communities with which the researchers have maintained relationships for 10 years, to work on resource recovery and to improve the quality of life of fishers through participatory methodologies, taking a comprehensive approach to help secure the future of fishery resource management. 
Table 1. List and definitions of Ostrom's design principles (Ostrom 1990, Cox et al. 2010). Principles were categorized (symbols) according to Ostrom (2009).

\begin{tabular}{|c|c|}
\hline Principle (Ostrom 1990, Cox et al. 2010) & Definition (Cox et al. 2010) \\
\hline P1A: Clearly defined user boundaries ${ }^{\dagger}$ & Clear boundaries between legitimate users and nonusers must be defined \\
\hline P1B: Clearly defined resource boundaries ${ }^{*}$ & $\begin{array}{l}\text { Clear boundaries are present that define a resource system and separate it from the larger } \\
\text { biophysical environment }\end{array}$ \\
\hline P2A: Congruence between rules and local conditions ${ }^{\S}$ & Appropriation and provision rules are congruent with local social and environmental conditions \\
\hline $\begin{array}{l}\text { P2B: Proportional equivalence between costs (provision rules) } \\
\text { and benefits (appropriation rules) }\end{array}$ & $\begin{array}{l}\text { Benefits obtained by users from a common-pool resource, as determined by appropriation rules, } \\
\text { are proportional to the amount of inputs required in the form of labor, material, or money, as } \\
\text { determined by provision rules }\end{array}$ \\
\hline P3: Collective-choice arrangements ${ }^{\dagger}$ & $\begin{array}{l}\text { Most individuals affected by the operational rules can participate in modifying the operational } \\
\text { rules }\end{array}$ \\
\hline P4A: Monitoring of rule enforcement ${ }^{\S}$ & $\begin{array}{l}\text { Monitors who are accountable to the users monitor the appropriation and provision levels of } \\
\text { the users }\end{array}$ \\
\hline P4B: Monitoring of resources ${ }^{*}$ & Monitors who are accountable to the users monitor the condition of the resource \\
\hline P5: Graduated sanctions $\S^{\S}$ & $\begin{array}{l}\text { Appropriators who violate operational rules are likely to be assessed graduated sanctions } \\
\text { (depending on the seriousness and the context of the offense) by other appropriators, officials } \\
\text { accountable to the appropriators, or both }\end{array}$ \\
\hline P6: Conflict-resolution mechanisms ${ }^{\S}$ & $\begin{array}{l}\text { Appropriators and their officials have rapid access to low-cost local arenas to resolve conflicts } \\
\text { among appropriators or between appropriators and officials }\end{array}$ \\
\hline P7: Minimal recognition of rights to organize ${ }^{\S}$ & $\begin{array}{l}\text { The rights of appropriators to devise their own institutions are not challenged by external } \\
\text { governmental authorities }\end{array}$ \\
\hline P8: Nested enterprises $\$$ & $\begin{array}{l}\text { Appropriation, provision, monitoring, enforcement, conflict resolution, and governance } \\
\text { activities are organized in multiple layers of nested enterprises }\end{array}$ \\
\hline
\end{tabular}

\section{METHODS}

\section{Description of the case studies}

Our study focused on small-scale marine fishers of the Taganga (Caribbean coast) and Tumaco (Pacific coast) communities (Fig. 1). The inhabitants are nationally and internationally known for their ancestral dependence on fishing. In Taganga, fieldwork was conducted over 3 mo (October-December 2015), whereas in Tumaco, fieldwork was conducted over 1 mo (March 2017).

In previous investigations, these communities have expressed an interest and willingness to participate in fishery management. They share similar fishery conditions and conflicts regarding the variety of methods and problems with the influence of external activities (e.g., tourism, port activities) and they have established informal regulations that they wish to formalize (Saavedra-Díaz 2012, Saavedra-Díaz et al. 2014, Jimenez-Torres and SaavedraDíaz 2019). Similarly, these communities have identified weaknesses that prevent them from advancing in this process, and they claim that they are not ready to manage their fishery resources autonomously; these weaknesses are closely related to Ostrom's SES framework (Table 2; Saavedra-Díaz et al. 2014, Jimenez-Torres and Saavedra-Díaz 2016). Therefore, our research was motivated by the need expressed by these communities to advance fishery comanagement.

Taganga is a coastal village in the district of Santa Marta (departmental capital). It has approximately 4500 inhabitants (Botero and Zielinski 2010); of the total population, approximately 300 people are small-scale marine fishers who use and exploit the fishery resources found in the coastal environment, reefs, and open sea and who exert an influence on the natural protected area of Tayrona National Natural Park (Saavedra-Díaz 2012). Furthermore, local fishers use a wide variety of fishing gear that ranges from chinchorros (seine nets), their traditional form of fishing, to relatively modern gear such as gillnets, handlines, set longlines, traps, and harpoons (Torres 2009, Saavedra-Díaz 2012). Taganga is the main small-scale marine fishing port in the department of Magdalena and is characterized as one of the most organized and developed landing points in the department. The small-scale marine fishing fleet is varied and ranges from cayucos (dugout canoes) or canoes (both oarpropelled) to engine-powered boats with greater fishing autonomy, known as pargueras (Bustos-Montes et al. 2012). Most fishers sell all or most of their catches to local buyers (De la $\mathrm{Hoz}$ et al. 2015).

Fig. 1. Maps of the study area, showing the community of Taganga on the Caribbean coast and the community of Tumaco on the Colombian Pacific coast.
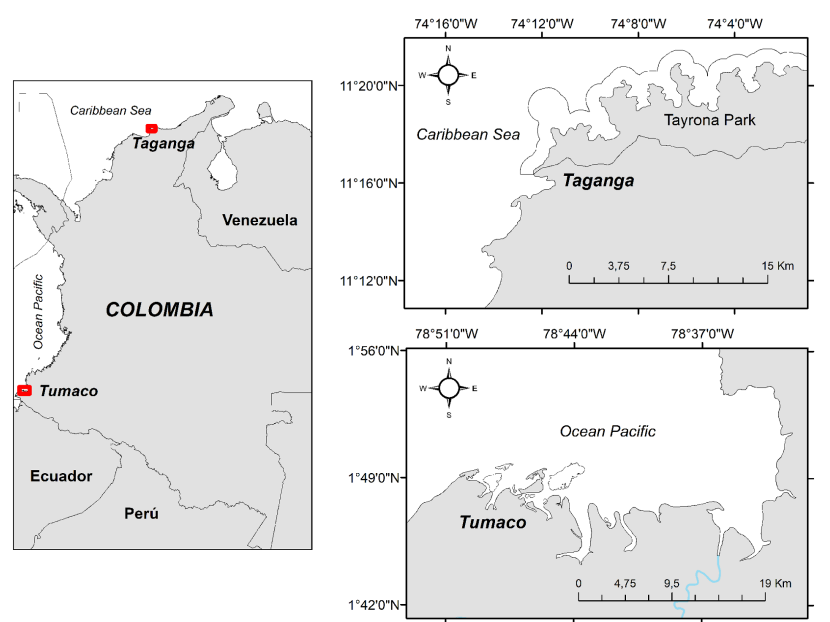
Table 2. Weaknesses identified by fishers in the case study communities based on the principles recommended by Ostrom (1990) to facilitate the comanagement of natural resources.

\begin{tabular}{|c|c|c|c|c|c|c|c|}
\hline \multirow[b]{2}{*}{ Principle } & \multirow[b]{2}{*}{ Weakness } & \multicolumn{3}{|c|}{ Taganga } & \multicolumn{3}{|c|}{ Tumaco } \\
\hline & & 2009 & 2012 & 2014 & 2009 & 2012 & 2014 \\
\hline \multirow{8}{*}{$\begin{array}{l}\text { P1A: Clearly defined } \\
\text { boundaries between } \\
\text { users }\end{array}$} & Absence of a fishery census & & $\mathrm{X}$ & $\mathrm{X}$ & & & $\mathrm{X}$ \\
\hline & $\begin{array}{l}\text { Territorial conflicts between tourism and fishing; fishing areas } \\
\text { are damaged by tourism }\end{array}$ & & & $\mathrm{X}$ & & & \\
\hline & Territorial conflicts with National Natural Parks & $\mathrm{X}$ & $\mathrm{X}$ & $\mathrm{X}$ & & & \\
\hline & The local fishers are being displaced by external fishers & $\mathrm{X}$ & $\mathrm{X}$ & $\mathrm{X}$ & & & \\
\hline & Decrease in the number of fishers & & & $\mathrm{X}$ & & & \\
\hline & The maritime fishing territory for the community is not delimited & & & & $\mathrm{X}$ & & $\mathrm{X}$ \\
\hline & Lack of regulation for foreign fishers & & & & $\mathrm{X}$ & $\mathrm{X}$ & $\mathrm{X}$ \\
\hline & Conflicts with industrial fishing & & & & $\mathrm{X}$ & & $\mathrm{X}$ \\
\hline \multirow{5}{*}{$\begin{array}{l}\text { P3: Collective choice } \\
\text { agreements }\end{array}$} & Low participation of fishers in decision making & $\mathrm{X}$ & $\mathrm{X}$ & $\mathrm{X}$ & $\mathrm{X}$ & $\mathrm{X}$ & $\mathrm{X}$ \\
\hline & Lack of local leaders with credibility and recognition & $\mathrm{X}$ & $\mathrm{X}$ & $\mathrm{X}$ & & $\mathrm{X}$ & $\mathrm{X}$ \\
\hline & Low participation of young people in fishery & & & $\mathrm{X}$ & & & \\
\hline & Fishers' attitudes & & & & $\mathrm{X}$ & & $\mathrm{X}$ \\
\hline & Fishers' denial of guilt over depletion & & & & $\mathrm{X}$ & & $\mathrm{X}$ \\
\hline \multirow{3}{*}{$\begin{array}{l}\text { P4A: Monitoring of } \\
\text { resources }\end{array}$} & Overused resources & & & & $\mathrm{X}$ & $\mathrm{X}$ & $\mathrm{X}$ \\
\hline & Unregulated fish size & & & & $\mathrm{X}$ & & \\
\hline & Inappropriate monitoring of fishery resources & & & & & & $\mathrm{X}$ \\
\hline \multirow{3}{*}{$\begin{array}{l}\text { P4B: Monitoring of } \\
\text { rule enforcement }\end{array}$} & Inappropriate fishing methods & & & & $\mathrm{X}$ & & $\mathrm{X}$ \\
\hline & Lack of regulations & & & & $\mathrm{X}$ & & \\
\hline & Corruption & & & & & $\mathrm{X}$ & $\mathrm{X}$ \\
\hline \multirow{5}{*}{$\begin{array}{l}\text { P5: Graduated } \\
\text { sanctions } \\
\text { P7: Minimal } \\
\text { recognition of right to } \\
\text { organize }\end{array}$} & Low participation of fishers in monitoring of rule enforcement & & & & & & $\mathrm{X}$ \\
\hline & Corruption & & & & & $\mathrm{X}$ & $\mathrm{X}$ \\
\hline & Conflicts with fishery organization leaders & & & & $\mathrm{X}$ & & $\mathrm{X}$ \\
\hline & Weak organization of fishers & & & & $\mathrm{X}$ & & $\mathrm{X}$ \\
\hline & Low organization of fishers & & & & & $\mathrm{X}$ & $\mathrm{X}$ \\
\hline \multirow[t]{7}{*}{ P8: Nested enterprises } & Lack of a union among fishers and lack of organization & $\mathrm{X}$ & $\mathrm{X}$ & $\mathrm{X}$ & & & \\
\hline & Most fishers are not part of fishers' associations & & & $\mathrm{X}$ & & & \\
\hline & Conflicts between fishers and institutions & & & & $\mathrm{X}$ & $\mathrm{X}$ & $\mathrm{X}$ \\
\hline & Lack of politicians with credibility and recognition & & & & & $\mathrm{X}$ & $\mathrm{X}$ \\
\hline & Conflicts of interest between fishers & & & $\mathrm{X}$ & & & $\mathrm{X}$ \\
\hline & Lack of a union among fishers & & & & & $\mathrm{X}$ & $\mathrm{X}$ \\
\hline & $\begin{array}{l}\text { Lack of governmental presence due to the insignificance of the } \\
\text { fishers }\end{array}$ & & & & $\mathrm{X}$ & & \\
\hline
\end{tabular}

The community of Tumaco is located in the southwestern region of the department of Nariño, approximately $300 \mathrm{~km}$ from San Juan de Pasto (departmental capital). It has an estimated population of 160,034 inhabitants. The local residents are mainly Afro-descendants or indigenous peoples who have preserved the traditional forms of territorial ownership and government (Vélez et al. 2012, Desarrollo con Identidad Regional Entre España y Nariño 2015). In the Tumaco urban area, 1709 people collect shellfish, mostly women known as piangüeras, whereas 4428 fishers (CORPESCA 2009) use and exploit the fishery resources found in the coastal area, mangroves, seabed, and open sea (Saavedra-Díaz 2012). For the extraction of fishery resources, a wide range of fishing gear and methods is used, from manual shellfish collection to the use of more modern equipment such as gillnets, surrounding nets, handlines, set longlines, and harpoons. The small-scale marine fishing fleet is varied and includes small boats such as canoes as well as boats with greater autonomy ( $\geq$ 40 horsepower engines) that rove the Colombian Pacific coast (Saavedra-Díaz 2012). Tumaco is one of the major fishing ports in the Colombian Pacific. Most small-scale marine fishers in Tumaco sell their catches in the local market. However, a significant proportion of such catches is also exported to neighboring countries such as Ecuador (De La Hoz et al. 2012).

In Colombia, fishery management has been adopted from a centralist approach (top-down). Therefore, the fisheries are owned by the state, and environmental and agricultural authorities share the responsibility for fishery and aquaculture governance (OECD 2016). At present, the Ministerio de Agricultura y Desarrollo Rural (Ministry of Agriculture and Rural Development), through the Autoridad Nacional de Acuicultura y Pesca (AUNAP; National Authority for Aquaculture and Fisheries), is formally in charge of the smallscale marine fisheries sector in Colombia. However, other government bodies are also responsible for fishing activities and fishing areas. Consequently, the governance system of small-scale marine fisheries in the country has undergone a process of fragmentation. This element, together with the division of responsibilities among the different competent institutions in the country, has historically generated uncertainty and has led to a lack of shared criteria to guide sector policies (Saavedra-Díaz and Jentoft 2017).

In the two case study communities, artisanal fisheries are managed under the centralist approach described above. In the community of Taganga, there are two central-level institutions in charge of fisheries administration: an AUNAP office and the Dirección Territorial Caribe de Parques Nacionales Naturales de Colombia (PNN; National Natural Parks of Colombia), with the latter intervening because the community is in the natural buffer zone protected area (Tayrona National Natural Park). In this community, AUNAP and PNN set regulations based on spatial 
Table 3. Characteristics of focus groups and participants in Taganga and Tumaco.

\begin{tabular}{|c|c|c|c|c|c|}
\hline \multirow[b]{2}{*}{$\begin{array}{l}\text { Focus group } \\
\text { community }\end{array}$} & \multicolumn{2}{|c|}{ Fishing gear or method } & \multirow[b]{2}{*}{$\begin{array}{c}\text { Duration of } \\
\text { discussion }(\mathrm{h})\end{array}$} & \multirow[b]{2}{*}{ Participants $(N)$} & \multirow[b]{2}{*}{$\begin{array}{c}\text { Mean participant age (yr } \pm \\
\text { standard deviation) }\end{array}$} \\
\hline & Local name & $\begin{array}{c}\text { Technical name } \\
\text { (Nédélec and Prado 1990) }\end{array}$ & & & \\
\hline Taganga & Chinchorro & Seine nets & 2.51 & 8 & $49.3 \pm 11.0$ \\
\hline (total 31 & Linea & Handlines & 1.59 & 5 & $46.2 \pm 10.4$ \\
\hline \multirow[t]{4}{*}{ participants) } & Nasa & Traps & 1.29 & 4 & $37 \pm 15.5$ \\
\hline & Pargueras & Handlines and set longlines & 1.51 & 4 & $57.6 \pm 2.6$ \\
\hline & Palangre & Set longlines & 1.56 & 5 & $35.6 \pm 15.0$ \\
\hline & Trasmallo & Gillnets & 2.13 & 5 & $39.0 \pm 7.2$ \\
\hline \multirow{8}{*}{$\begin{array}{l}\text { Tumaco } \\
\text { (total } 88 \\
\text { participants) }\end{array}$} & Boliche & Surrounding nets & 2.53 & 10 & $57.7 \pm 7.21$ \\
\hline & Cabo & Set longlines & 2.43 & 19 & $45.6 \pm 11.3$ \\
\hline & Chinchorro & Seine nets & 2.53 & 10 & $37.2 \pm 15.0$ \\
\hline & Espinel & Set longlines & 2.50 & 8 & $35.8 \pm 13.3$ \\
\hline & Piangüeras & Collectors & 2.33 & 12 & $51.8 \pm 12.5$ \\
\hline & $\begin{array}{l}\text { Collectors of other beach } \\
\text { species }\end{array}$ & Collectors & 2.55 & 7 & $47 \pm 8.2$ \\
\hline & Trasmallo & Gillnets & 2.28 & 12 & $39 \pm 11.1$ \\
\hline & Volantín & Handlines & 2.43 & 10 & $24.2 \pm 6.0$ \\
\hline
\end{tabular}

restrictions and zoning. In Tumaco, AUNAP is present and sets regulations based on temporal and spatial restrictions and restrictions and modifications of fishing gear, catch quotas, zoning, catch restrictions, and capture sizes. In both communities, regulations are established through mandatory administrative acts for fishers and the community in general. Similarly, the monitoring of compliance with regulations is supported by members of the Colombian National Navy, which is in charge of security in the marine area and the expedition of maritime traffic permits, including artisanal fishing.

\section{Data sources}

The local ecological knowledge (Berkes and Folke 2002, Charnley et al. 2007) possessed by the small-scale marine fishing communities of Taganga and Tumaco was used as a primary information source. To access this local knowledge, hearings were performed to start an informal discussion in which fishers brainstormed about the weaknesses that are closely related to Ostrom's SES framework and that affect small-scale marine fishing activity. Any fisher could identify a weakness or problem facing the community. These hearings were performed in 2009, 2012, and 2014 in both communities. The number of local community members participating in each hearing varied as follows: in Taganga, 22, 28, and 38 in 2009, 2012, and 2014, respectively; in Tumaco, 55, 20, and 105 in 2009, 2012, and 2014, respectively.

In addition to hearings, focus groups were conducted. This systematic qualitative method is used for data collection about processes (Bernard 2006). Six focus groups (Rabiee 2004) with 31 participants were conducted in Taganga during the period from October to December 2015. A focus group was arranged for each type of fishing gear currently used in the community (seine nets, gillnets, pargueras, set longlines, handlines, and traps; Table 3). Although we recognize diving as one of the fishing methods used in Taganga, fishers who use this method refused to participate in the research. In March 2017, eight focus groups with 88 participants were conducted in Tumaco. A focus group was established for each type of fishing gear or method currently used in that community (surrounding nets, set longlines, seine nets, set nets, piangüeras, collectors, gillnets, and handlines; Table 3). The selected fishers were referred by fishing leaders in each community, taking into account the fishing gear and crew.

In both communities, the traffic light metaphor was used; this metaphor made it possible to evaluate and visualize the fulfillment of goals and indicators according to the degree of progress. "Green" was assigned to the goals or indicators met, "yellow" to those that registered an advance, and "red" to those that were pending or with minimal advances (Ocho et al. 2012). Using the traffic light metaphor, the condition of Ostrom's eight design principles (Ostrom 1990, Cox et al. 2010) for successfully implementing comanagement was determined, and the eight principles were framed within Ostrom's (2009) categorization in the SES context (Table 1). This methodology allowed each fisher group to assign a traffic light color to each principle by consensus. Thus, the fishers assigned "red" to those principles that were absent in each community, which according to them needed immediate action, and "yellow" to those that they believed should be strengthened in the future. The "green" light was excluded, given that the processes of comanagement were in an incipient stage and the communities expressed weaknesses that did not allow them to advance in the implementation of systems for fishery resource comanagement (Saavedra-Díaz et al. 2014, Jimenez-Torres and Saavedra-Díaz 2016).

For each "red" principle, the fisher groups discussed and analyzed the reasons that motivated this categorization and proposed community and government solutions to strengthen the principle and to implement it in the community. In addition, the fishers identified possible conflicts that could arise when trying to advance such principles.

\section{Data analysis}

The qualitative information obtained from the hearings and focus groups was organized and coded using NVivo qualitative data analysis software (version 11, 2015, QSR International, Melbourne, Australia). This data analysis software is used to transform qualitative data into quantitative data. NVivo allows coders to identify and tag specific text segments and to associate them with a particular category or code. For the coding activities, 
content analysis was used; this methodology requires the identification of themes that appear in transcriptions of speech (Hruschka et al. 2004). The coding process was performed by a coder, and three-letter combinations were used to assign each code. The coding process created three major categories, which corresponded to the reasons, solutions, and future conflicts from the analysis of the prioritized principles proposed by the fishers. In this manner, 73 codes were obtained. Here, we focus on those principles that obtained $>60 \%$ prioritization in each community.

With a view to presenting a vision of the current status of each of the eight principles in the communities by fishing gear, statistical descriptions were used (percentages). Finally, to build a community vision of the fishers and to explore the relationships between the eight principles and the reasons for prioritization, redundancy analyses (RDAs) were performed for each community. RDA is a method of extracting and summarizing the variance in a set of response variables that can be explained by a set of explanatory variables. RDA is a direct gradient analysis technique that summarizes the linear relationships between the components of response variables that are redundant with (i.e., explained by) a set of explanatory variables. RDA is an alternative to canonical correlation analysis (Buttigieg and Ramette 2014).

\section{RESULTS}

We analyzed whether the small-scale marine fishing activities carried out in the communities of Taganga and Tumaco met the suggested conditions for comanagement of common-pool resources proposed by Ostrom (1990; Table 1). In this section, we describe the weaknesses in each community that prevent them from advancing in the comanagement process. We also describe the status of the principles according to the prioritization exercise completed by all the fishers and include an analysis of the reasons for their prioritization. We then present statistical analyses supporting the community vision in each of the communities studied. Finally, we analyze the possible community and government solutions and conflicts to identify opportunities to increase compliance with the principles.

\section{Weaknesses that prevent the communities of Tapanga and Tumaco from advancing in the comanagement process}

In each community, the fishers identified the weaknesses that prevent them from advancing in the comanagement process according to Ostrom's principles (Table 2). Our analysis shows an increase in the number of weaknesses in both communities over a short period of time $(5 \mathrm{yr})$. A significant number of weaknesses is identified by the fishers in Tumaco.

\section{Prioritizing the principles of success for the small-scale marine fishing activities in Taganga and Tumaco}

In both fishing communities, the urgent need to establish clear biophysical limits between resource users (P1A), collective choice arrangements (P3), and nested enterprises (P8) was noted. These principles were prioritized ("red" light) in both Taganga and Tumaco by $100 \%$ and $87.5 \%$ of participants, respectively. In particular, the community of Tumaco also prioritized work for monitoring resources (P4B) and rule enforcement (P4A), graduated sanctions (P5), and the minimal recognition of rights (P7; Table 4).
Table 4. Prioritization of the principles for success in Taganga and Tumaco calculated as the percentage of participants who believe that each principle should be prioritized ("red" light). Principles were categorized (symbols) according to Ostrom (2009).

\begin{tabular}{|c|c|c|}
\hline Principle (Ostrom 1990. Cox et al. 2010) & Taganga & Tumaco \\
\hline P1A: Clearly defined user boundaries ${ }^{\dagger}$ & $100 \%$ & $100 \%$ \\
\hline P1B: Clearly defined resource boundaries ${ }^{*}$ & $0.0 \%$ & $37.5 \%$ \\
\hline $\begin{array}{l}\text { P2A: Congruence between rules and local } \\
\text { conditions }\end{array}$ & $33.3 \%$ & $25.0 \%$ \\
\hline $\begin{array}{l}\text { P2B: Proportional equivalence between costs } \\
\text { (provision rules) and benefits (appropriation } \\
\text { rules) }\end{array}$ & $0.0 \%$ & $12.5 \%$ \\
\hline P3: Collective-choice arrangements ${ }^{\dagger}$ & $100 \%$ & $87.5 \%$ \\
\hline P4A: Monitoring of rule enforcement ${ }^{\S}$ & $0.0 \%$ & $87.5 \%$ \\
\hline P4B: Monitoring of resources ${ }^{*}$ & $0.0 \%$ & $87.5 \%$ \\
\hline P5: Graduated sanctions $\$$ & $0.0 \%$ & $75.0 \%$ \\
\hline P6: Conflict-resolution mechanisms $\$$ & $0.0 \%$ & $37.5 \%$ \\
\hline P7: Minimal recognition of right to organize ${ }^{\S}$ & $50.0 \%$ & $75.0 \%$ \\
\hline P8: Nested enterprises $\$$ & $100 \%$ & $87.5 \%$ \\
\hline
\end{tabular}

${ }^{\dagger}$ User system. $\quad{ }^{\ddagger}$ Resource system. $\quad{ }^{\S}$ Institutional system.

The reasons for prioritizing the principles are documented based on the local ecological knowledge of the small-scale marine fishers in Taganga and Tumaco. In Table 5, we list the reasons for prioritizing the principles considered "red" by both communities (P1A, P3, and P8), particularly Tumaco (P4A, P4B, P5, and P7). Additionally, the percentage for each of the reasons prioritized by each community is included, together with the codes assigned to each reason used in the statistical analysis (RDA). Although the reasons for prioritizing each principle are community-specific, some are highlighted by both communities, including the lack of communication between government bodies and the community, the restricted engagement of fishers in decision-making processes, the inefficiency and corruption of the sector institutions, violations of fishers' rights, and ineffective monitoring of resources and compliance with laws and regulations.

\section{Community vision of small-scale marine fishing activities in Taganga and Tumaco}

To explore the relationships between the principles, fishing gear, and reasons for prioritization and to build a community vision on the status of the principles, RDAs were carried out for each community. Although the methodological design proposed one analysis per type of fishing gear, when the gear is excluded from the analyses, a greater percentage of total variance is explained in each analysis. This difference indicates that there is a community vision of the status of the principles in each of the communities under study, regardless of the fishing gear used by the participants.

The RDA of Taganga establishes relationships between the principles prioritized ("red" light) and the reasons for prioritization ( $P<0.0001$, from 500 permutations). The first three factors account for $97.4 \%$ of the total variance (Table 6 ). The $\mathrm{x}$ axis $(F 1)$ represents $44.8 \%$ of the variance, showing a gradient between the principles: P1A, clearly defined user boundaries (negative scores); and P8, nested enterprises (positive scores). The $\mathrm{y}$-axis (F2) accounts for $35.8 \%$ of the variance, showing a gradient 
Table 5. Fishers' reasons for prioritizing Ostrom's design principles (Ostrom 1990, Cox et al. 2010) in two small-scale marine fishing communities in Colombia.

\begin{tabular}{|c|c|c|}
\hline Prioritized principle & $\operatorname{Code}^{\dagger}$ & Reason for prioritization \\
\hline \multirow[t]{4}{*}{ P1A: Clearly defined user boundaries } & npn & Fishing ban in Tayrona National Natural Park $\left(75.0^{\circ} \%^{\ddagger}\right)$ \\
\hline & ncg & Lack of communication between fishers and the government $\left(12.5 \%^{*}\right)$ \\
\hline & ncp & No fisher census $\left(12 . \%^{\star}\right)\left(46.6 \% \%^{\S}\right)$ \\
\hline & dpv & Violation of fisher rights $\left(53.3 \%{ }^{\S}\right)$ \\
\hline \multirow[t]{7}{*}{ P3: Collective-choice arrangements } & npa & Lack of fisher engagement in decision-making processes $\left(62.5 \%{ }^{\star}\right)\left(46.6 \%{ }^{\S}\right)$ \\
\hline & gss & Unsocialized government decisions $\left(25.0 \% \%^{\star}\right)$ \\
\hline & npa & Lack of participation of other stakeholders $\left(12.5 \% \%^{\star}\right)$ \\
\hline & ncg & Lack of communication between fishers and the government $\left(20.0 \%{ }^{\S}\right)$ \\
\hline & npa & Lack of participation of other stakeholders in the fisheries sector $\left(20.0 \% 0^{\S}\right)$ \\
\hline & dpv & Violation of fisher rights $\left(6.6 \%{ }^{\S}\right)$ \\
\hline & ilp & Local institutions are not involved in the fisheries sector $\left(6.6 \%{ }^{\S}\right)$ \\
\hline \multirow[t]{3}{*}{ P4A: Monitoring of rule enforcement } & $\mathrm{nmr}$ & Lack of monitoring of compliance with rules $\left(60.0 \% 0^{\S}\right)$ \\
\hline & pdn & Fisher does not know the regulations $\left(20.0^{\S}\right)^{\S}$ \\
\hline & cor & Lack of operability and/or presence of corruption of the sector institutions $\left(20.0 \%{ }^{\S}\right)$ \\
\hline P4B Monitoring the resources & $\mathrm{nmr}$ & Lack of fishery resources monitoring $\left(100 \%{ }^{\S}\right)$ \\
\hline \multirow[t]{3}{*}{ P5: Graduated sanctions } & $\sin$ & Ineffective or nonexistent sanctions $\left(77.7 \% \%^{\S}\right)$ \\
\hline & & cor: lack of operability and/or corruption of the sector institutions $\left.\left(22.2^{\%}\right)^{\S}\right)$ \\
\hline & cor & Lack of operability and/or presence of corruption of the sector institutions $(22.2 \%)$ \\
\hline \multirow{4}{*}{$\begin{array}{l}\text { P7: Minimal recognition of right to } \\
\text { organize }\end{array}$} & ilp & Local institutions are not involved in the fisheries sector $\left(33.3 \%^{\dagger}\right)$ \\
\hline & dpv & Violation of fisher rights $\left(33.3 \%{ }^{\ddagger}\right)\left(30.0^{\S}\right)$ \\
\hline & anr & Stakeholders in the fisheries sector with no representation $\left(33.3 \%^{*}\right)\left(40.0^{\%} 0^{\S}\right)$ \\
\hline & cor & Lack of operability and/or presence of corruption of the sector institutions $\left(30.0 \%{ }^{\S}\right)$ \\
\hline \multirow[t]{2}{*}{ P8: Nested enterprises } & ntc & Lack of community work $\left(66.6 \%{ }^{\star}\right)\left(72.7 \%{ }^{\S}\right)$ \\
\hline & nag & Lack of support for the fishers and the community $\left(33.3 \%^{\star}\right)\left(27.2^{\S} \%^{\S}\right)$ \\
\hline
\end{tabular}

between the reasons: the lack of fisher participation (npp; negative scores) and the fishing ban in Tayrona National Natural Park (npn; positive scores).

Table 6. Redundancy analysis results for the reasons for prioritizing the principles of success in Taganga.

\begin{tabular}{llll}
\hline \hline Parameter & F1 & F2 & F3 \\
\hline Eigenvalue & 0.243 & 0.194 & 0.091 \\
Constrained inertia (\%) & 44.776 & 35.803 & 16.785 \\
Cumulative \% & 44.776 & 80.579 & 97.363 \\
Total inertia & 27.026 & 21.610 & 10.131 \\
\hline
\end{tabular}

The RDA plot of the reasons represented by the first two axes (Fig. 2) shows that from a community perspective, the principles that should be immediately strengthened are P1A (clearly defined user boundaries), P8 (nested enterprises), and P3 (collective choice arrangements). These principles are prioritized for all fishing gear types or methods.

The RDA for Tumaco (Fig. 3) establishes the relationships between the principles that have been prioritized ("red" light) and the reasons for their prioritization $(P<0.0001$, from 500 permutations). The first three factors account for $55.0 \%$ of the total variance (Table 7). The $\mathrm{x}$-axis (F1) represents $21.30 \%$ of the variance, showing a gradient between the principles from $\mathrm{P} 1 \mathrm{~A}$, clearly defined user boundaries (positive scores), to P8, nested enterprises (negative scores). The y-axis (F2) accounts for 18.5\% of the variance, showing a gradient between the lack of monitoring of fishery resources (nmr; negative scores) and the lack of fisher participation (npp; positive scores).
Fig. 2. Redundancy analysis biplot of the reasons for prioritizing each of the design principles, obtained through focus groups in Taganga. The $\mathrm{x}$-axis (F1) accounts for $44.8 \%$ of the variance, and the $y$-axis (F2) accounts for $35.8 \%$. See Tables 1 and 5 for definitions.

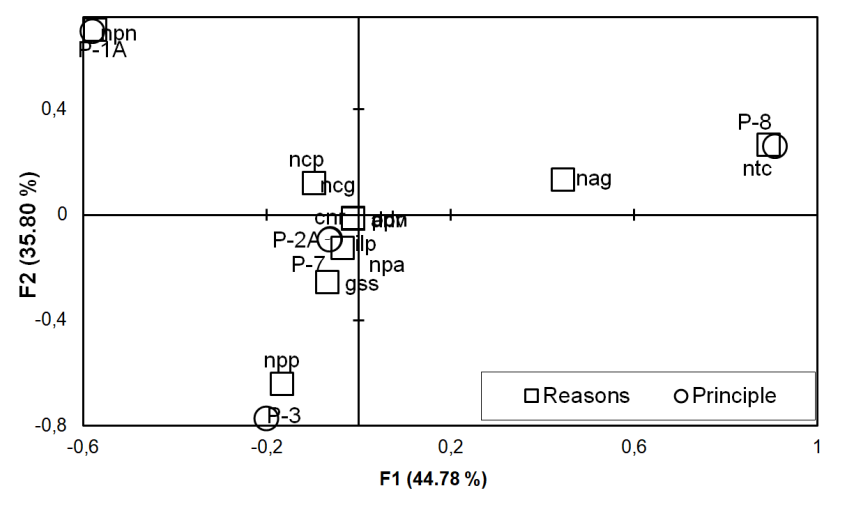

\section{DISCUSSION}

Fishery exploitation is considered the primary human disturbance in coastal ecosystems, and its open-access condition has contributed to the collapse of fish stocks (Pomeroy and Rivera-Guieb 2006, Jackson et al. 2001). Marine fishing is a complex and dynamic activity (Berkes et al. 2001) involving various actors. Each actor has an individual interest; thus, it becomes necessary to implement a governance system capable of 
bringing together all interested parties (Bavinck et al. 2005). From this perspective, community-based conservation is a viable option for fishery resource management in the Anthropocene (Gutiérrez et al. 2011, Ban et al. 2017, Redmore et al. 2018).

Table 7. Redundancy analysis results for the reasons for prioritizing the principles of success in Tumaco.

\begin{tabular}{llll}
\hline \hline Parameter & F1 & F2 & F3 \\
\hline Eigenvalue & 0.099 & 0.086 & 0.070 \\
Constrained inertia (\%) & 21.332 & 18.455 & 15.197 \\
Cumulative \% & 21.332 & 39.787 & 54.984 \\
Total inertia & 10.829 & 9.369 & 7.715 \\
\hline
\end{tabular}

Fig. 3. Redundancy analysis biplot of the reasons for prioritizing each of the design principles, obtained through focus groups in Tumaco. The x-axis (F1) accounts for $22.0 \%$ of the variance, and the $y$-axis (F2) accounts for $17.1 \%$. See Tables 1 and 5 for definitions.

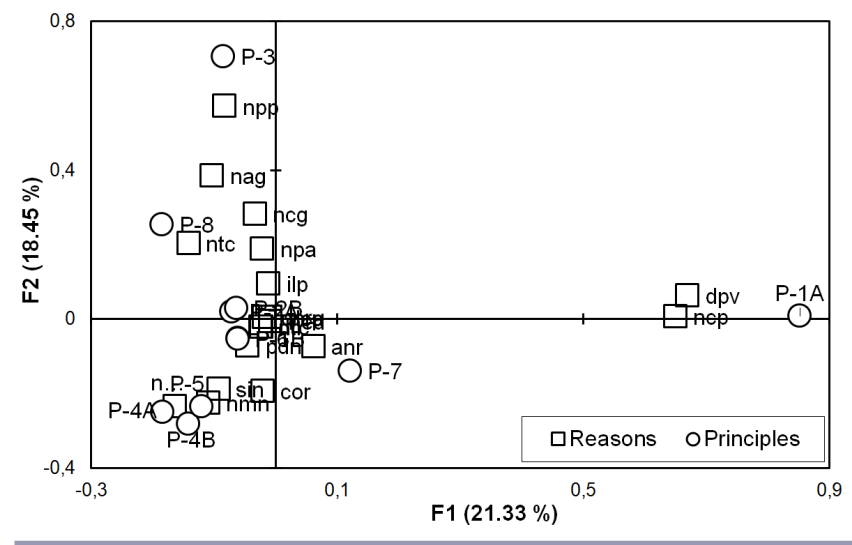

In Colombia, fishing has been managed from a centralist approach, and thus, key actors such as fishers are left out of the administration and decision-making processes (Cuello and Duarte 2010, García 2010, OECD 2016). Our study, conducted from the perspective of local fishers, shows that assessing the principles of success from this perspective may guide the transition from a top-down management model to a comanagement-based model in Colombia, as documented by Trimble and Berkes (2015) for another Latin American country. Previous studies conducted with different actors in the Colombian fisheries sector have noted that $>50.0 \%$ of such actors believe that a bottom-up management scheme is possible in the future and that joint work between communities and the fisheries administration is required (Saavedra-Díaz et al. 2015a, 2016).

The descriptive analyses (Tables 2 and 4) and RDAs (Figs. 2 and 3) are congruent and allowed a community analysis to be performed when the RDAs did not show significant differences among the different fishing gear types or methods. A significant percentage of fishers in this research believe that principles P1A (Taganga: 100\%; Tumaco: 87.5\%), P3 (Taganga: 100\%; Tumaco: $87.5 \%$ ), and P8 (Taganga: $100 \%$; Tumaco: $87.5 \%$ ) are critically important. Therefore, there is a critical situation with respect to principle P1A (clearly defined user boundaries) in both communities because of the multiple uses assigned to a single fishing ground (protected area, small-scale fishing, aquaculture, port activities, tourism, and diving), including illegal activities such as drug trafficking and the presence of foreign users and opportunists (Saavedra-Díaz 2012), and the lack of set institutional hierarchal levels for such arrangements. In line with our results, other studies carried out on fishery resources have also categorized clearly defined user boundaries as absent (Pinkerton and Weinstein 1995, Ernst et al. 2013, Fleischman et al. 2014, Trimble and Berkes 2015). To advance this principle, a community territory must first be defined based on political jurisdiction, and then the communities that share this territory for fishing grounds must be identified through political intervention (Saavedra-Díaz 2012, Trimble and Berkes 2015). Additionally, real resource users should be identified (legitimate fishers), and control on foreign users and opportunists should be imposed (Berkes 2015, Saavedra-Díaz et al. 2016). Considering that unclear territorial boundaries affect both governance and compliance with other principles (Fleischman et al. 2014), the open-access condition of fisheries only serves to worsen such blurred boundaries, fostering resource overexploitation and exacerbating the tragedy of the commons that surrounds these types of resources in developing countries (Ostrom and Hess 2000, Kosamu 2015, Baggio et al. 2016, Bresnihan 2019).

The basis for prioritizing P3 is the lack of collective choice arrangements, the weak organizational capacity of the community, and the lack of community work. In addition, although fisher organizations exist in Taganga and Tumaco, fishing issues are rarely addressed in meetings. Thus, fishers do not attend or are altogether excluded from such meetings (Fleischman et al. 2014, Trimble et al. 2014, Trimble and Berkes 2015). In light of these circumstances, in these communities, the design and implementation of participatory methodologies that respond not only to group or community approaches but also to individual approaches (Berkes 2009, Saavedra-Díaz 2012) are necessary. Moreover, it is essential to encourage the participation of legitimate fishers in the decision-making process (SaavedraDíaz et al. 2016); users should at least be consulted about the establishment of policies and institutional changes even if they were not previously considered during the decision-making stage (Fleischman et al. 2014).

The absence of empowered community organizations, the lack of community work, and the establishment of institutional hierarchal levels for enforcing regulations and agreements, supervision, implementation, conflict resolution, and governance, according to that which is established by P8 (nested enterprises; Cox et al. 2010, Trimble and Berkes 2015, Baggio et al. 2016), substantiate this prioritization. Given the multiple uses of the fishing areas in both communities, this principle may be essential for establishing biophysical limits between resource users (P1A) and resource limits (P1B; Cox et al. 2010, Fleischman et al. 2014) Therefore, delegation of authority to the communities and the creation of committees at all levels where fishers can come together, such as in communities and local, regional, and national institutions, are essential. In this way, a network can be established for maintaining effective communication (Saavedra-Díaz 2012), fostering an equitable distribution of authority (Berkes 2009), and designing systems that decentralize power, such as polycentric systems (Carlsson 2000, Fleischman et al. 2014), horizontal 
Table 8. Conflicts and solutions to advance the principles identified as priorities by the small-scale marine fishers of two communities in Colombia.

\begin{tabular}{|c|c|c|}
\hline Principle & Conflicts & Solutions \\
\hline $\begin{array}{l}\text { P1A: Clearly } \\
\text { defined user } \\
\text { boundaries }\end{array}$ & $\begin{array}{l}\text { None }\left(87.7 \%^{\dagger}\right) \\
\text { Disagreement between fishers and the fishing administration } \\
\left(25.0^{\dagger} \%^{\dagger}\right)\left(14 . \%^{\dagger}\right) \\
\text { Lack of communication between government and the } \\
\text { community }\left(25.0^{\dagger}\right) \\
\text { Lack of fisher engagement }\left(12.5 \%{ }^{\dagger}\right) \\
\text { Unemployment }\left(12.5 \%^{\dagger}\right) \\
\text { Proliferation of illegal activities }\left(12.5 \%{ }^{\dagger}\right)\end{array}$ & 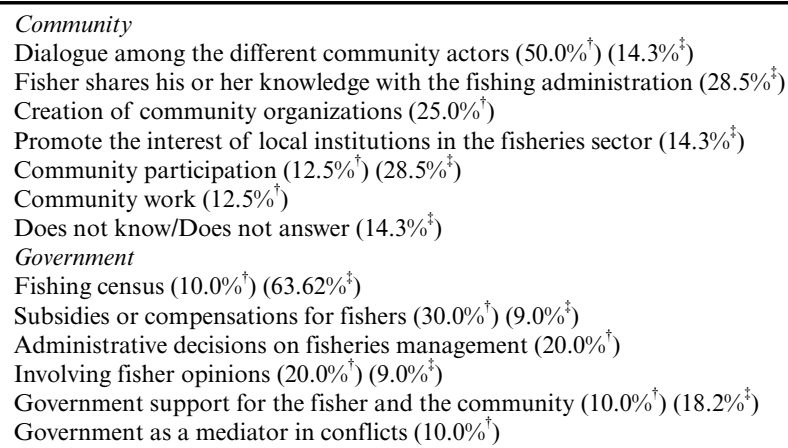 \\
\hline $\begin{array}{l}\text { P3: Collective- } \\
\text { choice } \\
\text { arrangements }\end{array}$ & $\begin{array}{l}\text { None }\left(25.0^{\dagger} \%^{\dagger}\right)\left(71.4 \%^{\dagger}\right) \\
\text { Lack of fisher engagement }\left(37.5 \%{ }^{\dagger}\right) \\
\text { Disagreement between fishers and the fishing administration } \\
\left(28.5 \%^{\dagger}\right) \\
\text { Disagreement between fishers }\left(25.0 \%^{\dagger}\right) \\
\text { Mistrust toward government agencies }\left(12.5 \%^{\dagger}\right)\end{array}$ & 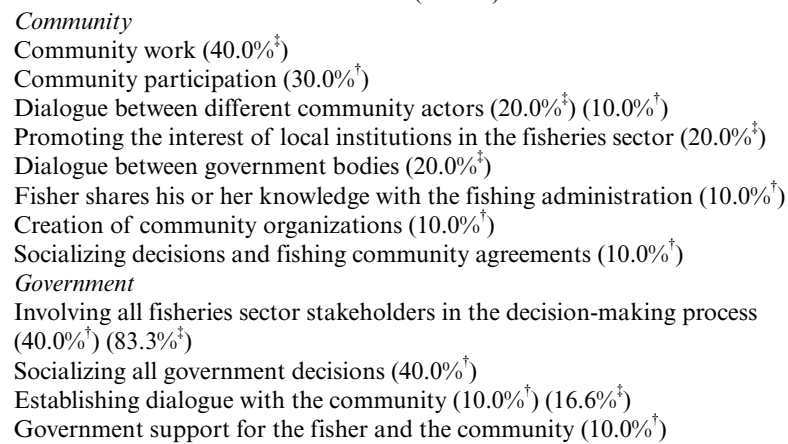 \\
\hline $\begin{array}{l}\text { P4A: Monitoring of } \\
\text { rule enforcement }\end{array}$ & $\begin{array}{l}\text { Disagreement between fishers and the fishing administration } \\
\left(42.8 \%^{*}\right) \\
\text { None }\left(28.5 \%^{*}\right) \\
\text { Violation of regulations }\left(14.2 \%^{*}\right)\end{array}$ & $\begin{array}{l}\text { Community } \\
\text { Community participation }\left(50 . \%^{*}\right) \\
\text { Monitoring compliance with regulations }\left(25.0^{*}\right) \\
\text { Promoting the interest of local institutions in the fisheries sector }\left(25.0^{*} \%^{*}\right) \\
\text { Government } \\
\text { Monitoring compliance with regulations }\left(50.0 \%{ }^{*}\right) \\
\text { Fighting corruption }\left(25 . \%^{*}\right) \\
\text { Government support for the fisher and the community }\left(12.5 \%{ }^{\dagger}\right) \\
\text { Subsidies or compensation for fishers }\left(12.5 \%{ }^{*}\right)\end{array}$ \\
\hline $\begin{array}{l}\text { P4B: Monitoring of } \\
\text { resources }\end{array}$ & $\begin{array}{l}\text { Disagreement between fishers and the fishing administration } \\
\left(71.4 \%^{*}\right) \\
\text { None }\left(28.5 \%^{*}\right)\left(25 . \%^{*}\right) \\
\text { Does not know/Does not answer }\left(14.3 \%^{*}\right)\end{array}$ & $\begin{array}{l}\text { Community } \\
\text { Monitoring the resources }\left(50.0 \%^{*}\right) \\
\text { Community participation }\left(50 . \%^{*}\right) \\
\text { Government } \\
\text { Monitoring the resources }\left(38.4 \%{ }^{*}\right) \\
\text { Training fishers }\left(30.7 \%^{*}\right) \\
\text { Socializing all government decisions }\left(15.4^{*} \%^{*}\right) \\
\text { Subsidies or compensation for fishers }\left(7.7 \% 0^{*}\right) \\
\text { Establishing dialogue with the community }\left(7.7 \%{ }^{*}\right)\end{array}$ \\
\hline $\begin{array}{l}\text { P8: Nested } \\
\text { enterprises }\end{array}$ & $\begin{array}{l}\text { None }\left(50.0^{\dagger} 0^{\dagger}\right)\left(33.3 \%^{\dagger}\right) \\
\text { Corruption }\left(33.3 \%^{\dagger}\right) \\
\text { Disagreement among fishers }\left(33.3 \%^{\star}\right) \\
\text { Disagreement between fishers and the fishing administration } \\
\left(16.6 \%^{\dagger}\right) \\
\text { Lack of fisher engagement }\left(16.6 \%{ }^{\dagger}\right)\end{array}$ & 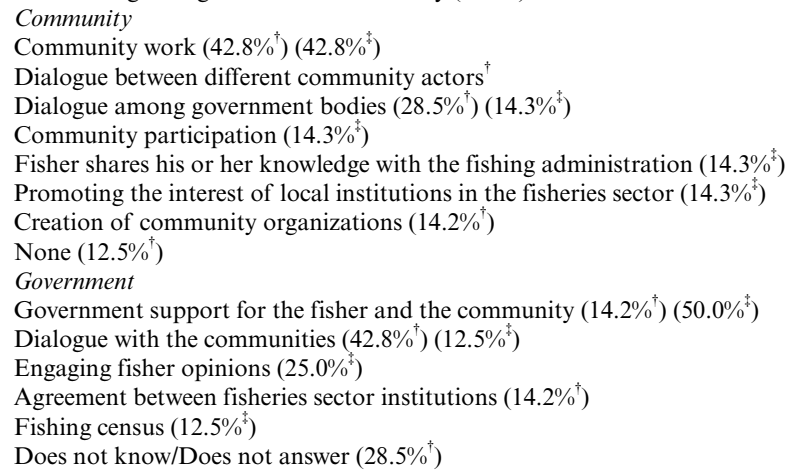 \\
\hline
\end{tabular}


interactions (Fleischman et al. 2014), and policy networks (Carlsson 2000, McGinnis 2000).

With priorities $>80.0 \%$, Tumaco, in particular, prioritizes principles P4A (monitoring rule enforcement, 87.5\%) and $\mathrm{P} 4 \mathrm{~B}$ (monitoring resources, 87.5\%). With similar significant percentages, Tumaco also prioritizes principles P5 (graduated sanctions, $75.0 \%$ ) and $\mathrm{P} 7$ (minimal recognition of right to organize, $75.0 \%$ ). These prioritizations are significant because they result from lacking or having insufficient monitoring processes carried out by the government or by fishers who fail to report violations of formal regulations or the use of inappropriate fishing gear. The fishers in Taganga do not prioritize these principles because they said that government bodies (e.g., Dirección General Marítima [General Maritime Directorate], AUNAP, and PNN) work in monitoring rule enforcement and resources, achieving results due to proximity to the capital city, whose economy depends on tourism and port activities (Aguilera Díaz and Alvis Arrieta 2000, Viloria-de-la-Hoz 2015).

However, the aforementioned situation in Taganga does not ensure full compliance with these principles. To strengthen and advance principles P4A, P4B, and P5, fishers and leaders recommend regulating the fisheries sector (Saavedra-Díaz et al. 2016), improving the fishing authority infrastructure, and coordinating national and local fishery policies. These efforts will encourage collaborative monitoring of compliance with regulations and of resources under governmental supervision (Fleischman et al. 2014, Berkes 2015, Saavedra-Díaz et al. 2016) and will help to avoid bribes and favor enforcement (Trimble and Berkes 2015, Saavedra-Díaz et al. 2016), thereby promoting the involvement of civil society and the international community interested in natural resource protection (Fleischman et al. 2014), and to encourage participatory research in which fishers and researchers work side by side (Saavedra-Díaz et al. 2016). The weaknesses identified in 2009, 2012, and 2014 (Table 2) coincide with the reasons expressed by the fishers in both communities when they prioritized the principles in 2017 (Table 4) and with the approaches made by other authors.

We acknowledge differences between both case studies, notably, the number of principles prioritized by a significant proportion of fishers in the community of Taganga is lower than that prioritized by fishers in Tumaco. However, this should not be understood as better preparation in the community of Taganga for the implementation of a system for fishery resource comanagement because previous studies of these communities reflect that, in general terms, Pacific communities are more aware of the need for regulations (Saavedra-Díaz et al. 2016). Furthermore, Tumaco, in particular, has made significant progress toward the comanagement of its resources through lobbying processes and the empowerment of marine fishers (Beardon 2008, Saavedra-Díaz et al. 2014, Jiménez-Torres 2016).

Understanding the common framework that describes and explains an SES also fosters an understanding of the processes that lead to resource improvement or deterioration (Ostrom 2009). The common framework for an SES connects and feeds back to the existing mutual relationships in the complex social system composed of the institutional system and the user system and to the ecological system composed of the resource system and resource units (Ostrom 2009, McGinnis and Ostrom 2014).
This connection illustrates the link between the principles framed in each of these systems (Table 4), thus demonstrating the importance and need for complying with the principles to enable the successful implementation of comanagement in small-scale fisheries. However, the design principles of Ostrom (1990) can be wrongly interpreted as universal keys to success, or as a signal of disaster if absent, if the social and ecological contexts are not taken into account (Aswani et al. 2017).

When advancing the implementation of a participatory management strategy such as comanagement, the emergence of conflicts between the actors involved seems unavoidable. However, these conflicts may be regarded as a triggering factor or opportunity to move forward in the process (Pomeroy and Berkes 1997, Plummer and FitzGibbon 2004, Trimble and Berkes 2015) or as a challenge posed to such a process (Napier et al. 2005, Pomeroy 2007, Armitage et al. 2009). The cross-cutting conflicts identified by our study (conflicts of interest, lack of community work, and participation) are considered determinants of the failure of adaptive comanagement processes (Plummer et al. 2012, Trimble and Berkes 2015).

However, simply identifying the conflicts that arise in a comanagement process is insufficient; it is necessary to envision the steps to follow to advance the process effectively (SaavedraDíaz et al. 2016). Therefore, we identify the conflicts that hinder the enforcement of the principles of success in these communities. Furthermore, from a local perspective, our research brings together the mechanisms (solutions) that make it possible to move forward and to face the conflicts that hinder compliance with the principles of success prioritized by each community (Table 8).

\section{CONCLUSIONS}

Ostrom's design principles (Ostrom 1990, Cox et al. 2010) have contributed to identifying and analyzing the weaknesses, reasons, solutions, and conflicts involved in the attempt to implement a comanagement strategy in the small-scale marine fishing activities of Taganga and Tumaco. In addition, such principles provide a prescriptive approach for implementing policies related to the intention to transition toward comanagement. At this critical juncture in the history of Colombia, with the post-peace agreement with the Fuerzas Armadas Revolucionarias de Colombia (FARC; Revolutionary Armed Forces of Colombia), and recognizing that other violent actors remain in the territory and have come to fill the power vacuum left by FARC, actions are urgently needed to strengthen these principles in rural communities to empower fishers and to allow them to respond adequately to the challenges posed both presently and in the future.

Although our analysis of the design principles of Ostrom's SES framework is a mere snapshot that needs to be replicated over time to include external factors (Trimble and Berkes 2015), our study provides evidence that the case study communities are not yet prepared to implement a management strategy such as comanagement. Despite this shortcoming, local actors show a willingness to move forward to overcome the barriers that prevent them from making progress, and these barriers are directly related to resource users and the government system. These results indicate a need to create institutional arrangements between interested parties at multiple levels and to reflect the importance of governance and how the lack thereof has contributed to the 
overexploitation and poor state of small-scale marine fishing both worldwide (Coastal Resources Center 2006) and in Colombia (Saavedra-Díaz et al. 2015a, 2016). In addition, our study shows the usefulness of Ostrom's SES framework for evaluating the possibility of establishing comanagement in the SES of smallscale marine fisheries and as a tool for building robust governance structures for the participatory management of small-scale marine fisheries in the Anthropocene.

At this moment, this research is pertinent in both case study communities because the fishers in the "En busca de herramientas de manejo pesquero participativo en Colombia" ("In search of participatory fishing management tools in Colombia;" Unimagdalena-AUNAP 2014-2015) framework research project have proposed tools for comanaging fishery resources. Therefore, for both fishers and AUNAP, the assessment of the principles of Ostrom's SES framework presented here reveals that this framework is an instrument for implementing such tools because it shows the urgent need to work on aspects that are key for managing common-pool resources.

Responses to this article can be read online at: http://www.ecologyandsociety.org/issues/responses. php/11299

\section{Acknowledgments:}

This research was possible because of the participation and collaboration with Colombian marine fishers and local leaders from the communities of Taganga and Tumaco, with special thanks to the fishing leaders Luis Matos, Juan Asis Tejeda, Evert Ledesma, and Maria de Los Santos Valencia. We are thankful to Gloria De León, Jaime Gonzalez, Jesús Jiménez, and María De Los Ángeles González for their help with the fieldwork. This study was partially supported by the Departamento Administrativo de Ciencia, Tecnología e Innovación (COLCIENCIAS) [Administrative Department of Science, Technology and Innovation] under the program "Convocatoria para la formación de capital humano de alto nivel para el departamento del Magdalena-2014 (convocatoria 672 Cap. 1, Jóvenes Investigadores) [Call for the formation of highlevel human capital for the department of Magdalena-2014 (Call 672 Chapter 1, Young Researchers) ]", the Office of the Vice Rector for Research at the University of Magdalena, and the Fundación Para la Investigación, Conservación y Desarrollo Sostenible de los Socio-Ecosistemas.

\section{LITERATURE CITED}

Agüero, M., and M. Claverí. 2007. Capacidad de pesca y manejo pesquero en América Latina: una síntesis de estudios de casos. Pages 61-72 in M. Agüero, editor. Capacidad de pesca y manejo pesquero en América Latina y el Caribe. FAO Documento Técnico de Pesca 461. Food and Agriculture Organization, Rome, Italy. [online] URL: http://www.fao.org/3/a0236s/a0236s00.htm

Aguilera Díaz, M. M., and J. L. Alvis Arrieta. 2000. Perfil socioeconómico de Barraquilla, Cartagena y Santa Marta (19902000). Banco de la República, Bogotá, Colombia. [online] URL: https://www.banrep.gov.co/es/perfil-socioeconomico-barranquillacartagena-y-santa-marta-1990-2000

Anderson, L. G., and J. C. Seijo. 2010. Bioeconomics of fisheries management. Wiley, New York, New York, USA.

Armitage, D., F. Berkes, and N. Doubleday. 2007. Adaptive comanagement: collaboration, learning, and multi-level governance. UBC Press, Vancouver, Canada.

Armitage, D. R., R. Plummer, F. Berkes, R. I. Arthur, A. T. Charles, I. J. Davidson-Hunt, A. P. Diduck, N. C. Doubleday, D. S. Johnson, M. Marschke, P. McConney, E. W. Pinkerton, and E. K. Wollenberg. 2009. Adaptive co-management for socialecological complexity. Frontiers in Ecology and the Environment 7(2):95-102. https://doi.org/10.1890/070089

Aswani, S., X. Basurto, S. Ferse, M. Glaser, L. Campbell, J. E. Cinner, T. Dalton, L. D. Jenkins, M. L. Miller, R. Pollnac, I. Vaccaro, and P. Christie. 2018. Marine resource management and conservation in the Anthropocene. Environmental Conservation 45(2):192-202. https://doi.org/10.1017/S0376892917000431

Autoridad de los Recursos Acuáticos de Panamá. 2016. Anteproyecto de ley que regula la pesca, la acuicultura y las actividades conexas en la República de Panamá y se dictan otras disposiciones. Autoridad de los Recursos Acuáticos de Panamá, Panama City, Panama. [online] URL: https://arap.gob.pa/wpcontent/uploads/2017/08/Borrador-final-Ley-de-Pesca-Discusio $\%$ CC\%81n.pdf

Baggio, J. A., A. J. Barnett, I. Perez-Ibarra, U. Brady, E. Ratajczyk, E., N. Rollins, C. Rubiños, H. C. Shin, D. J. Yu, R. Aggarwal, J. M. Anderies, and M. A. Janssen. 2016. Explaining success and failure in the commons: the configural nature of Ostrom's institutional design principles. International Journal of the Commons 10(2):417-439. http://doi.org/10.18352/ijc.634

Ban, N. C., C. Whitney, T. E. Davies, E. Buscher, D. Lancaster, L. Eckert, C. Rhodes, and A. L. Jacob. 2017. Conservation actions at global and local scales in marine social-ecological systems: status, gaps, and ways forward. Pages 143-168 in P. S. Levin and M. R. Poe, editors. Conservation for the Anthropocene ocean. Academic Press, Cambridge, Massachusetts, USA. https://doi. org/10.1016/B978-0-12-805375-1.00008-8

Basurto, X., S. Gelcich, and E. Ostrom. 2013. The socialecological system framework as a knowledge classificatory system for benthic small-scale fisheries. Global Environmental Change 23 (6):1366-1380. https://doi.org/10.1016/j.gloenvcha.2013.08.001

Bavinck, M., R. Chuenpagdee, M. Diallo, P. van der Heijden, J. Kooiman, R. Mahon, and S. Williams. 2005. Interactive fisheries governance: a guide to better practice. Eburon Publishers, Delft, Amsterdam. [online] URL: http://www.marecentre.nl/fishgovfood/ documents/bavinck interactive.pdf

Beardon, H. 2008. Building hope from chaos: culture, politics and the protection of the Colombian Pacific mangroves. World Wildlife Fund, Godalming, UK. [online] URL: http://assets. panda.org/downloads/reflections_on change colombia ing web final. pdf

Belhabib, D., U. R. Sumaila, and D. Pauly. 2015. Feeding the poor: contribution of West African fisheries to employment and 
food security. Ocean and Coastal Management 111:72-81. https:// doi.org/10.1016/j.ocecoaman.2015.04.010

Béné, C. 2006. Small-scale fisheries: assessing their contribution to rural livelihoods in developing countries. FAO Fisheries Circular 1008. Food and Agriculture Organization, Rome, Italy. [online] URL: http://agris.fao.org/agris-search/search.do?recordID= GB2013201564

Berkes, F. 2009. Evolution of co-management: role of knowledge generation, bridging organizations and social learning. Journal of Environmental Management 90(5):1692-1702. https://doi.org/10.1016/ j.jenvman.2008.12.001

Berkes, F. 2010. Shifting perspectives on resource management: resilience and the reconceptualization of 'natural resources' and 'management'. Maritime Studies 9(1):13-40.

Berkes, F. 2015. Coasts for people: interdisciplinary approaches to coastal and marine resource management. Routledge, New York, New York, USA. https://doi.org/10.4324/9781315771038

Berkes, F., and C. Folke. 2002. Back to the future: ecosystem dynamics and local knowledge. Pages 121-146 in L. H. Gunderson and C. S. Holling, editors. Panarchy: understanding transformations in human and natural systems. Island Press, Washington, D.C., USA.

Berkes, F., R. Mahon, P. McConney, R. Pollnac, and R. Pomeroy. 2001. Managing small-scale fisheries: alternative directions and methods. International Development Research Centre, Ottawa, Canada.

Bernard, H. R. 2006. Research methods in anthropology: qualitative and quantitative approaches. Sixth edition. Rowman and Littlefield, Lanham, Maryland, USA.

Botero, C., and S. Zielinski. 2010. Evaluación del potencial para el desarrollo de turismo sostenible en el corregimiento de Taganga, distrito de Santa Marta (Colombia). Turismo y Sociedad 11:10-34. [online] URL: https://revistas.uexternado.edu.co/index. php/tursoc/article/view/2825

Bresnihan, P. 2019. The (slow) tragedy of improvement: neoliberalism, fisheries management \& the institutional commons. World Development 120:210-220. https://doi. org/10.1016/j.worlddev.2017.09.017

Bustos-Montes, D., F. J. Cuello, S. Salas-Castro, A. Saza, J. De La Hoz, M. Grijalba-Bendeck, C. Posada-Peláez, A. SantaféMuñoz, and J. Cuellar-Pinzón. 2012. Variación espacio-temporal del desembarco pesquero artesanal marítimo del departamento del Magdalena, Caribe colombiano. Pages 41-112 in M. GrijalbaBendeck, D. Bustos-Montes, C. Posada Peláez, and A. SantaféMuñoz, editors. La pesca artesanal maritima del departamento del Magdalena (Colombia): una visión desde cuatro componentes. Fundación Universidad de Bogotá Jorge Tadeo Lozano, Ministerio de Agricultura y Desarrollo Rural, Proyecto Transición de la Agricultura, Bogotá, Colombia.

Buttigieg, P. L., and A. Ramette. 2014. A guide to statistical analysis in microbial ecology: a community-focused, living review of multivariate data analyses. FEMS Microbiolgy Ecology 90 (3):543-550. https://doi.org/10.1111/1574-6941.12437
Carlsson, L. 2000. Policy networks as collective action. Policy Studies Journal 28(3):502-520. http://dx.doi.org/10.1111/j.1541-0072.2000. $\underline{\mathrm{tb} 02045 . \mathrm{x}}$

Castilla, J. C., and O. Defeo. 2001. Latin American benthic shellfisheries: emphasis on co-management and experimental practices. Reviews in Fish Biology and Fisheries 11(1):1-30. https:// doi.org/10.1023/A:1014235924952

Castilla, J. C., and M. Fernandez. 1998. Small-scale benthic fisheries in Chile: on co-management and sustainable use of benthic invertebrates. Ecological Applications 8(sp1):S124-S132. https://doi.org/10.1890/1051-0761(1998)8[S124:SBFICO]2.0.CO;2

Charnley, S., A. P. Fischer, and E. T. Jones. 2007. Integrating traditional and local ecological knowledge into forest biodiversity conservation in the Pacific Northwest. Forest Ecology and Management 246(1):14-28. https://doi.org/10.1016/j.foreco.2007.03.047

Cinner, J. E., T. R. McClanahan, M. A. MacNeil, N. A. J. Graham, T. M. Daw, A. Mukminin, D. A. Feary, A. L. Rabearisoa, A. Wamukota, N. Jiddawi, S. J. Campbell, A. H. Baird, F. A. Januchowski-Hartley, S. Hamed, R. Lahari, T. Morove, and J. Kuange. 2012. Co-management of coral reef social-ecological systems. Proceedings of the National Academy of Sciences 109 (14):5219-5222. https://doi.org/10.1073/pnas.1121215109

Coastal Resources Center. 2006. Fisheries opportunities assessment. Coastal Resources Center, University of Rhode Island, South Kingstown, Rhode Island, USA. [online] URL: http://www.crc.uri.edu/download/Fish Opp Assess Final 012607508. pdf

Corporación para el desarrollo de la pesca (CORPESCA). 2009. Censo de pescadores artesanales del Municipio de Tumaco. Alcaldía Municipal de San Andrés de Tumaco y CORPESCA, Tumaco, Colombia.

Corporación para el Desarrollo Sostenible del Urabá. 2005. Plan de manejo integral de los manglares del golfo de Urabá y mar Caribe Antioqueño. Consejo comunitario de Bocas del Atrato y Leoncito, Turbo, Colombia.

Costello, C. J., and D. Kaffine. 2008. Natural resource use with limited-tenure property rights. Journal of Environmental Economics and Management 55(1):20-36. https://doi.org/10.1016/ j.jeem.2007.09.001

Cox, M., G. Arnold, and S. Villamayor Tomás. 2010. A review of design principles for community-based natural resource management. Ecology and Society 15(4):38. https://doi. org/10.5751/ES-03704-150438

Crona, B., S. Gelcich, and Ö. Bodin. 2017. The importance of interplay between leadership and social capital in shaping outcomes of rights-based fisheries governance. World Development 91:70-83. https://doi.org/10.1016/j.worlddev.2016.10.006

Cuello, F., and L. O. Duarte. 2010. El pescador artesanal, fuente de información ecológica para la ordenación pesquera en el mar Caribe de Colombia. Proceedings of the Gulf and Caribbean Fisheries Institute 62:463-470.

De la Hoz, J., L. Manjarrés-Martínez, and F. Cuello. 2015. Estadísticas de desembarco, esfuerzo, valor monetario y rentas de 
la pesquería artesanal de Taganga período abril-diciembre de 2015. Autoridad Nacional de Acuicultura y Pesca, Bogotá, Colombia. [online] URL: http://sepec.aunap.gov.co/Home/VerPdf/24

De La Hoz, J., J. C. Narváez, L. Manjarrés-Martínez, L. Nieto A., R. Rivera, F. Cuello, and T. Álvarez. 2012. Reporte de la actividad pesquera industrial y artesanal continental y marina de Colombia. Universidad del Magdalena, Bogotá, Colombia. [online] URL: http://sepec.aunap.gov.co/Home/VerPdf/14

Desarrollo con Identidad Regional Entre España y Nariño. 2015. Plan estratégico y operativo del sector de la pesca artesanal del pacífico nariñense. Agencia de Desarrollo Local de Nariño, Pasto, Colombia. [online] URL: https://www.direna.org/wp-content/ uploads/2016/08/repo-2-1.pdf

Ernst, B., J. Chamorro, P. Manríquez, J. M. Lobo Orensanz, A. M. Parma, J. Porobic, and C. Román. 2013. Sustainability of the Juan Fernández lobster fishery (Chile) and the perils of generic science-based prescriptions. Global Environmental Change 23 (6):1381-1392. https://doi.org/10.1016/j.gloenvcha.2013.08.002

Evans, L., N. Cherrett, and D. Pemsl. 2011. Assessing the impact of fisheries co-management interventions in developing countries: a meta-analysis. Journal of Environmental Management 92(8):1938-1949. https://doi.org/10.1016/j.jenvman.2011.03.010

Fargier, L., H. J. Hartmann, and H. Molina-Ureña. 2014. "Marine areas of responsible fishing": a path toward small-scale fisheries co-management in Costa Rica? Perspectives from Golfo Dulce. Pages 155-181 in F. Amezcua and B. Bellgraph, editors. Fisheries management of Mexican and Central American estuaries. Springer, Dordrecht, The Netherlands. https://doi. org/10.1007/978-94-017-8917-2 10

Feeny, D., F. Berkes, B. J. McCay, and J. M. Acheson. 1990. The tragedy of the commons: twenty-two years later. Human Ecology 18(1):1-19. https://doi.org/10.1007/BF00889070

Fleischman, F. D., N. C. Ban, L. S. Evans, G. Epstein, G. GarciaLopez, S. Villamayor-Tomas. 2014. Governing large-scale socialecological systems: lessons from five cases. International Journal of the Commons 8(2):428-456. http://doi.org/10.18352/ijc.416

Food and Agriculture Organization. 2012. El estado mundial de la pesca y la acuicultura. Food and Agriculture Organization, Rome, Italy. [online] URL: http://www.fao.org/3/a-i2727s.pdf

Fundación Ecosfera. 2006. Fortalecimiento integral de la pesca artesanal de las comunidades de pescadores Wayúu, area de influencia de los municipios de Manaure y Riohacha, Departamento de la Guajira. Fundación Ecosfera y Chevron Texaco, Riohacha, Colombia. [online] URL: http://guajira360.org/wp-content/ uploads/2018/09/Fortalecimiento-Pesca-Artesanal-Wayuu.pdf

Gadgil, M., P. Olsson, F. Berkes, and C. Folke. 2002. Exploring the role of local ecological knowledge in ecosystem management: three case studies. Pages 189-209 in F. Berkes, J. Colding, and C. Folke, editors. Navigating social-ecological systems: building resilience for complexity and change. Cambridge University Press, Cambridge, UK. https://doi.org/10.1017/CBO9780511541957.013

Galappaththi, E. K., and F. Berkes. 2015. Drama of the commons in small-scale shrimp aquaculture in northwestern Sri Lanka. International Journal of the Commons 9(1):347-368. http://doi. org/10.18352/ijc. 500
García, C. B. 2010. Conocimiento tradicional: lo que los pescadores artesanales del Caribe colombiano tienen para decirnos. Pan-American Journal of Aquatic Sciences 5(1):78-90.

García Lozano, A. J., and J. T. Heinen. 2015. Identifying drivers of collective action for the co-management of coastal marine fisheries in the Gulf of Nicoya, Costa Rica. Environmental Management 57(4):759-769. https://doi.org/10.1007/s00267-015-0646-2

Gelcich, S., G. Edwards-Jones, M. J. Kaiser, and J. C. Castilla. 2006. Co-management policy can reduce resilience in traditionally managed marine ecosystems. Ecosystems 9 (6):951-966. https://doi.org/10.1007/s10021-005-0007-8

Gelcich, S., T. P. Hughes, P. Olsson, C. Folke, O. Defeo, M. Fernández, S. Foale, L. H. Gunderson, C. Rodríguez-Sickert, M. Scheffer, R. S. Steneck, and J. C. Castilla. 2010. Navigating transformations in governance of Chilean marine coastal resources. Proceedings of the National Academy of Sciences 107 (39):16794-16799. https://doi.org/10.1073/pnas.1012021107

Gelcich, S., M. J. Martínez-Harms, S. Tapia-Lewin, F. VasquezLavin, and C. Ruano-Chamorro. 2019. Comanagement of smallscale fisheries and ecosystem services. Conservation Letters 12(2): e12637. https://doi.org/10.1111/conl.12637

Gutiérrez, N. L., R. Hilborn, and O. Defeo. 2011. Leadership, social capital and incentives promote successful fisheries. Nature 470(7334):386-389. https://doi.org/10.1038/nature09689

Hruschka, D. J, D. Schwartz, D. C. St.John, E. Picone-Decaro, R. A. Jenkins, and J. W. Carey. 2004. Reliability in coding openended data: lessons learned from HIV behavioral research. Field Methods 16(3):307-331. http://dx.doi.org/10.1177/1525822X04266540

Jackson, J. B. C., M. X. Kirby, W. H. Berger, K. A. Bjorndal, L. W. Botsford, B. J. Bourque, R. H. Bradbury, R. Cooke, J. Erlandson, J. A. Estes, T. P. Hughes, S. Kidwell, C. B. Lange, H. S. Lenihan, J. M. Pandolfi, C. H. Peterson, R. S. Steneck, M. J. Tegner, and R. R. Warner. 2001. Historical overfishing and the recent collapse of coastal ecosystems. Science 293(5530):629-637. https://doi.org/10.1126/science.1059199

Jentoft, S. 2003. Co-management - the way forward. Pages 1-14 in D. C. Wilson, J. R. Nielsen, and P. Degnbol, editors. The fisheries co-management experience: accomplishments, challenges and prospects. Springer, Dordrecht, The Netherlands. http://dx. doi.org/10.1007/978-94-017-3323-6

Jiménez-Torres, J. M. 2016. Evaluación de normas formales e informales como herramientas para el manejo pesquero artesanal marino-costero en dos comunidades de pescadores en Colombia. Dissertation. Universidad del Magdalena, Santa Marta, Colombia. [online] URL: http://repositorio.unimagdalena.edu. co/jspui/handle/123456789/1385

Jiménez-Torres, J. M., and L. M. Saavedra-Díaz. 2019. Evaluating formal and informal rules as a basis for implementing coastal marine artisanal fisheries management in Colombia. Marine Policy 101:225-236. https://doi.org/10.1016/j.marpol.2018.09.019

Kosamu, I. B. M. 2015. Conditions for sustainability of smallscale fisheries in developing countries. Fisheries Research 161:365-373. https://doi.org/10.1016/j.fishres.2014.09.002

McCay, B. J., F. Micheli, G. Ponce-Díaz, G. Murray, G. Shester, S. Ramirez-Sanchez, and W. Weisman. 2014. Cooperatives, 
concessions, and co-management on the Pacific coast of Mexico. Marine Policy 44:49-59. https://doi.org/10.1016/j.marpol.2013.08.001

McGinnis, M. D., editor. 2000. Polycentric games and institutions: readings from the workshop in political theory and policy analysis. University of Michigan Press, Ann Arbor, Michigan, USA. https://doi.org/10.3998/mpub.10728

McGinnis, M. D., and E. Ostrom. 2014. Social-ecological system framework: initial changes and continuing challenges. Ecology and Society 19(2):30. http://dx.doi.org/10.5751/ES-06387-190230

Mendoza, S. L., J. Higinio Maldonado, and R. Moreno. 2008. Pescando futuro: la participación de las comunidades en la exploración de escenarios de conservación. Universidad de los Andes, Bogotá, Colombia.

Napier, V. R., G. M. Branch, and J. M. Harris. 2005. Evaluating conditions for successful co-management of subsistence fisheries in KwaZulu-Natal, South Africa. Environmental Conservation 32 (2):165-177. https://doi.org/10.1017/S0376892905002195

Navia, A. F., P. A. Mejía-Falla, L. Gómez, L. Payán, A. Ramírez, and A. Tobón. 2008. Pesquerías y cadena productiva del recurso tiburón en el Pacífico colombiano: análisis y perspectivas. Documento Técnico Fundación Squalus FS0108. Squalus, Cali, Colombia.

Navia, A. F., P. A. Mejía-Falla, J. López-García, L. A. Muñoz, and V. Ramírez-Luna. 2010. Pesquería artesanal de la zona norte del Pacífico colombiano: aportando herramientas para su administración, fase II. Documento Técnico Fundación Squalus FS0110. Squalus, Cali, Colombia.

Nédélec, C., and J. Prado. 1990. Definition and classification of fishing gear categories. FAO Fisheries Technical Paper 222, revision 1. Food and Agriculture Organization, Rome, Italy. [online] URL: http://www.fao.org/3/t0367t/t0367t00.htm

Ocho, D. L., P. C. Struik, L. L. Price, E. Kelbessa, and K. Kolo. 2012. Assessing the levels of food shortage using the traffic light metaphor by analyzing the gathering and consumption of wild food plants, crop parts and crop residues in Konso, Ethiopia. Journal of Ethnobiology and Ethnomedicine 8:30. https://doi. org/10.1186/1746-4269-8-30

Olsson, P., C. Folke, and F. Berkes. 2004. Adaptive comanagement for building resilience in social-ecological systems. Environmental Management 34:75-90. https://doi.org/10.1007/s00267-003-0101-7

Orensanz, J. M., A. Cinti, A. M. Parma, L. Burotto, S. EspinosaGuerrero, E. Sosa-Cordero, C. Sepúlveda, and V. Toral-Granda. 2013. Latin American rights-based fisheries targeting sedentary resources. Pages 1-69 in J. M. Orensanz and J. C. Seijo, editors. Rights-based management in Latin American fisheries. FAO Fisheries and Aquaculture Technical Paper 582. Food and Agriculture Organization, Rome, Italy. [online] URL: http://www. fao.org/3/a-i3418e.pdf

Organisation for Economic Co-operation and Development (OECD). 2016. Fisheries and aquaculture in Colombia. OECD, Paris, France. [online] URL: https://www.oecd.org/countries/ colombia/Fisheries Colombia 2016.pdf

Ostrom, E. 1990. Governing the commons: the evolution of institutions for collective action. Cambridge University Press, Cambrige, UK.
Ostrom, E. 2005. Understanding institutional diversity. Princeton University Press, Princeton, New Jersey, USA.

Ostrom, E. 2009. A general framework for analyzing sustainability of social-ecological systems. Science 325 (5939):419-422. https://doi.org/10.1126/science.1172133

Ostrom, E., and C. Hess. 2000. Private and common property rights. Pages 332-379 in D. W. Allen, B. Bouckaert, and G. De Geest, editors. Encyclopedia of law and economics. University of Ghent, Ghent, Belgium. https://doi.org/10.4337/9781849806510.00008

Ostrom, E., M. A. Janssen, and J. M. Anderies. 2007. Going beyond panaceas. Proceedings of the National Academy of Sciences 104(39):15176-15178. https://doi.org/10.1073/pnas.0702288104

Pinkerton, E., and M. Weinstein. 1995. Fisheries that work: sustainability through community-based management. David Suzuki Foundation, Vancouver, Canada.

Plummer, R., B. Crona, D. R. Armitage, P. Olsson, M. Tengö, and O. Yudina. 2012. Adaptive comanagement: a systematic review and analysis. Ecology and Society 17(3):11. http://dx.doi. org/10.5751/ES-04952-170311

Plummer, R., and J. FitzGibbon. 2004. Co-management of natural resources: a proposed framework. Environmental Management 33(6):876-885. https://doi.org/10.1007/s00267-003-3038y

Pomeroy, R. 2007. Conditions for successful fisheries and coastal resources co-management: lessons learned in Asia, Africa, and the wider Caribbean. Pages 172-187 in D. Armitage, F. Berkes, and N. Doubleday, editors. Adaptive co-management: collaboration, learning, and multi-level governance. UBC Press, Vancouver, Canada.

Pomeroy, R. S., and F. Berkes. 1997. Two to tango: the role of government in fisheries co-management. Marine Policy 21 (5):465-480. https://doi.org/10.1016/S0308-597X(97)00017-1

Pomeroy, R. S., P. McConney, and R. Mahon. 2004. Comparative analysis of coastal resources co-management in the Caribbean. Ocean and Coastal Management 47(9-10):429-447. https://doi. org/10.1016/j.ocecoaman.2004.09.005

Pomeroy, R. S., and R. Rivera-Guieb. 2006. Fishery comanagement: a practical handbook. CABI, Wallingford, UK.

Poteete, A. R., M. A. Janssen, and E. Ostrom. 2010. Working together: collective action, the commons, and multiple methods in practice. Princeton University Press, Princeton, New Jersey, USA. 215-247.

Rabiee, F. 2004. Focus-group interview and data analysis. Proceedings of the Nutrition Society 63(4):655-660. https://doi. org/10.1079/PNS2004399

Ramírez-Luna, Á. V. 2013. The exclusive fishing zone for the artisanal fishery in Chocó Colombia: origins, development, and consequences for artisanal fisheries and food security. Thesis. Memorial University of Newfoundland and Labrador, St. John's, Canada. [online] URL: https://research.library.mun.ca/12113/1/ Ramirez.pdf

Redmore, L., A. Stronza, A. Songhurst, and G. McCulloch. 2018. Which way forward? Past and new perspectives on communitybased conservation in the Anthropocene. Encyclopedia of the 
Anthropocene 3:453-460. https://doi.org/10.1016/ B978-0-12-809665-9.09838-4

Ruitenbeek, J., and C. Cartier. 2001. The invisible wand: adaptative co-management as an emergent strategy in complex bio-economic systems. Occasional Paper 34. Center for International Foresty Research, Bogor, Indonesia. [online] URL: http://dlc.dlib. indiana.edu/dlc/bitstream/handle/10535/5019/OP-034.pdf? sequence $=1 \&$ is Allowed $=\mathrm{y}$

Saavedra-Díaz, L. M. 2012. Towards Colombian small-scale marine fisheries management: hacia un manejo de la pesca marina artesanal en Colombia. Dissertation. University of New Hampshire, Durham, New Hampshire, USA. [online] URL: https://scholars.unh.edu/cgi/viewcontent.cgi?article $=1658 \&$ context $=$ dissertation

Saavedra-Díaz, L. M., and S. Jentoft. 2017. The role of the smallscale fisheries guidelines in reclaiming human rights for smallscale fishing people in Colombia. Pages 573-594 in S. Jentoft, R. Chuenpagdee, M. J. Barragán-Paladines, and N. Franz, editors. The small-scale marine fisheries guidelines: global implementation. Springer, Cham, Switzerland. https://doi.org/10.1007/978-3-319$\underline{-55074-927}$

Saavedra-Díaz, L. M., L. Manjarés-Martinéz, L. O. Duarte, D. Botto-Barrios, C. Ángel-Yunda, and M. A. González-Pabón. 2014. Informe técnico final: proyecto buscando herramientas de manejo pesquero en Colombia con base en el conocimiento tradicional de pescadores artesanales marino-costeros. Autoridad Nacional de Acuicultura y Pesca-AUNAP, Fundación SQUALUS, Universidad del Magdalena, Santa Marta, Colombia.

Saavedra-Díaz, L. M., R. Pomeroy, and A. A. Rosenberg. 2016. Managing small-scale marine fisheries in Colombia. Maritime Studies 15(1):6. https://doi.org/10.1186/s40152-016-0047-z

Saavedra-Díaz, L. M., A. A. Rosenberg, and B. Martín-López. 2015a. Social perceptions of Colombian small-scale marine fisheries conflicts: insights for management. Marine Policy 56:61-70. https://doi.org/10.1016/j.marpol.2014.11.026

Saavedra-Díaz, L. M., A. A. Rosenberg, and R. Pomeroy. $2015 b$. Why Colombian marine fishers' knowledge is a fundamental tool for marine resource management and assessment. Pages 89-106 in J. Fischer, J. Jorgensen, H. Josupeit, D. Kalikoski, and C. M. Lucas, editors. Fishers' knowledge and the ecosystem approach to fisheries: applications, experiences and lessons in Latin America. FAO Fisheries and Aquaculture Technical Paper 591. Food and Agriculture Organization, Rome, Italy. [online] URL: http://www. fao.org/3/a-i4664e.pdf

Salas, S., R. Chuenpagdee, J. C. Seijo, and A. Charles. 2007. Challenges in the assessment and management of small-scale marine fisheries in Latin America and the Caribbean. Fisheries Research 87(1):5-16. https://doi.org/10.1016/j.fishres.2007.06.015

Santos-Martínez, A., J. E. Mancera Pineda, E. Castro González, M. Sjogreen Velasco, H. B. Hooker, and J. Torres Rodríguez. 2013. Propuesta para el manejo pesquero de la zona sur del área marina en la Reserva de Biosfera Seaflower - Archipiélago de San Andrés, Providencia y Santa Catalina, Caribe Colombiano. Editorial Unibiblios, Bogotá, Colombia.
Schumann, S. 2007. Co-management and "consciousness": fishers' assimilation of management principles in Chile. Marine Policy 31(2):101-111. https://doi.org/10.1016/j.marpol.2006.05.008

Schusler, T. M., D. J. Decker, and M. J. Pfeffer. 2003. Social learning for collaborative natural resource management. Society and Natural Resources 16(4):309-326. https://doi. org/10.1080/08941920390178874

Seixas, C. S., C. V. Minte-Vera, R. G. Ferreira, R. L. Moura, I. B. Curado, J. Pezzuti, A. P. G. Thé, and R. B. Francini-Filho. 2009. Co-managing commons: advancing aquatic resources management in Brazil. Pages 156-182 in P. Lopes and A. Begossi, editors. Current trends in human ecology. Cambridge Scholars Publishing, Newcastle upon Tyne, UK. https://doi.org/10.5848/CSP.0441.00007

Silva, C. N. S., M. K. Broadhurst, R. P. Medeiros, and J. H. Dias. 2013. Resolving environmental issues in the southern Brazilian artisanal penaeid-trawl fishery through adaptive co-management. Marine Policy 42:133-141. https://doi.org/10.1016/j.marpol.2013.02.002

Torres, J. A. 2009. Aspectos bioeconómicos de la pesca marina artesanal en el norte del Departamento del Magdalena entre marzo $y$ octubre de 2009, Caribe Colombiano. Undergraduate Thesis. Universidad de Bogotá Jorge Tadeo Lozano, Bogotá, Colombia. [online] URL: http://hdl.handle.net/20.500.12010/1281

Torres-Guevara, L. E., A. Schlüter, and M. C. Lopez. 2016. Collective action in a tropical estuarine lagoon: Adapting Ostrom's SES framework to Ciénaga Grande de Santa Marta, Colombia. International Journal of the Commons 10(1):334-362. http://doi.org/10.18352/ijc.623

Trimble, M., and F. Berkes. 2015. Towards adaptive comanagement of small-scale fisheries in Uruguay and Brazil: lessons from using Ostrom's design principles. Maritime Studies 14(1):14. https://doi.org/10.1186/s40152-015-0032-y

Trimble, M., L. Gomes de Araujo, and C. S. Seixas. 2014. One party does not tango! Fishers' non-participation as a barrier to co-management in Paraty, Brazil. Ocean and Coastal Management 92:9-18. https://doi.org/10.1016/j.ocecoaman.2014.02.004

United Nations Environment Programme. 2007. Global environment outlook 4: environment for development. United Nations Environment Programme, Nairobi, Kenya. [online] URL: $\underline{\text { http://hdl.handle.net/20.500.11822/7646 }}$

United Nations Environment Programme. 2012. Global environment outlook 5: environment for the future we want. United Nations Environment Programme, Nairobi, Kenya. [online] URL: http://hdl.handle.net/20.500.11822/8021

Vélez, M. A., J. K. Stranlund, and J. J. Murphy. 2012. Preferences for government enforcement of a common pool harvest quota: theory and experimental evidence from fishing communities in Colombia. Ecological Economics 77:185-192. https://doi. org/10.1016/j.ecolecon.2012.02.030

Viloria-de-la-Hoz, J. 2015. Ciudades portuarias del Caribe colombiano: propuestas para competir en una economía globalizada. Banco de la República de Colombia Documentos de Trabajo sobre Economía Regional y Urbana 80. Banco de la República de Colombia, Bogotá, Colombia. https://doi. org/10.32468/dtseru. 80 
Wilson, D. C., J. R. Nielsen, and P. Degnbol, editors. 2003. The fisheries co-management experience: accomplishments, challenges and prospects. Springer, Dordrecht, The Netherlands. https://doi. org/10.1007/978-94-017-3323-6

Zapata, L. 2005. El manejo de los recursos pesqueros en los parques nacionales. Estudio caso: Pacifico Colombiano. Unidad Administrativa Especial del Sistema de Parques Nacionales Naturales, Ministerio del Medio Ambiente y Desarrollo, Bogotá, Colombia.

Zapata, L. 2006. Diagnóstico y caracterización de los recursos hidrobiológicos en el PNN Sanquianga y su zona de influencia, como parte de una propuesta para la implementación de un plan de manejo. Unidad Administrativa Especial del Sistema de Parques Nacionales Naturales, Ministerio del Medio Ambiente y Desarrollo, Bogotá, Colombia. 